INVITED REVIEW ARTICLE

\title{
非小細胞肺癌に対する周術期治療としての 免疫チェックポイント阻害薬の有用性
}

\author{
鈴木弘行 1 -猪俣 頌 1 - 山口 光 1 峯 勇人 1 高木玄教 1 ・ \\ 尾崎有紀 1 ・渡部晶之 $1 \cdot$ 井上卓哉 1 福原光朗 1 - 山浦 匠 1 - \\ 武藤哲史 $1 \cdot$ 岡部直行 $1 \cdot$ 松村勇輝 $1 \cdot$ 長谷川剛生 $1 \cdot$ 大杉 $\quad$ 純 1 . \\ 星野実加 $1 \cdot$ 樋口光徳 $1 \cdot$ 塩 豊 1
}

\section{Efficacy of Immune-checkpoint Inhibitors as the Peri-operative Treatment for Resectable Non-small-cell Lung Cancer}

\author{
Hiroyuki Suzuki1; Sho Inomatal; Hikaru Yamaguchi1; Hayato Mine1; Hironori Takagi1; \\ Yuki Ozaki1; Masayuki Watanabe1; Takuya Inoue1; Mitsuro Fukuhara1; Takumi Yamaura1; \\ Satoshi Muto1; Naoyuki Okabel; Yuki Matsumural; Takeo Hasegawa1; Jun Osugi1; \\ Mika Hoshino1; Mitsunori Higuchi1; Yutaka Shio1 \\ ${ }^{1}$ Department of Chest Surgery, Fukushima Medical University, Japan.
}

\begin{abstract}
The development of immune-checkpoint inhibitors (ICIs) has revolutionized the treatment of advanced and/or recurrent non-small-cell lung cancer (NSCLC), mainly in the driver gene-negative subset. In stage IV NSCLC, ICIs have been widely applied not only as monotherapy but also in combination with cytotoxic chemotherapeutic agents. Furthermore, in recent years, ICIs combination therapy has also become available. In cases of unresectable stage III locally advanced NSCLC, ICIs have been shown to be effective as maintenance therapy after chemo-radiotherapy and are now available in clinical practice. This trend has led to the expectation of the efficacy of ICIs for earlier-stage resectable NSCLC. A number of phase III trials are now underway for perioperative treatment, mainly for stage II-III NSCLC, and some drugs have already been submitted for approval. However, there are some issues that need to be addressed concerning their use, such as perioperative complications and the emergence of immune-related adverse events.
\end{abstract}

(JJLC. 2021;61:919-923)

KEY WORDS — Non-small-cell lung cancer, Immune-checkpoint inhibitor, Surgical treatment, Neo-adjuvant treatment, Adjuvant treatment

Corresponding author: Hiroyuki Suzuki.

要旨——免疫チェックポイント阻害薬（ICIs）の登場に よって進行再発非小細胞肺癌 (NSCLC) の治療法は大き く変化した. IV 期 NSCLCにおいてはドライバー遺伝子 を有さないNSCLC が主な適応とされているが，1 次治 療から 2 次治療以降にわたるまで ICIs 単独療法と殺細 胞性薬物療法との併用療法も含めて, 幅広く使われるよ うになった. 近年では ICIs の 2 剂併用療法も使用可能と なっている. 一方で切除不能 III 期局所進行肺癌では放 射線化学療法後の維持療法としての有効性も示され, 実
臨床で使用可能となった。このような進行肺癌における 治療成績を踏まえ, 早期である切除可能 NSCLCに対し ても ICIs の有効性が期待されることとなった. 周術期治 療として主に II〜III 期の NSCLCを対象に, 多くの第 III 相試験が進行中であり，一部は承認申請に至っている 薬剤もある。ただ，その使用においては周術期の合併症 や免疫学的有害事象の問題など, 注意すべき課題もある. 索引用語——非小細胞肺癌, 免疫チェックポイント阻害 薬, 外科療法, 術前補助療法, 術後補助療法 


\section{1. はじめに}

2015 年に進行再発非小細胞肺癌 (NSCLC) 治療におい て初めて免疫チェックポイント阻害薬 (ICIs) が臨床応用 され，現在では標準治療の中核を成す治療となった．現 在実臨床で使用可能な ICIs は抗 PD-1 抗体の Nivolumab, Pembrolizumab, 抗 PD-L1 抗体の Atezolizumab, Durvalumab，および抗 CTLA-4 抗体の Ipilimumabである.

これらのICIs は，まず進行再発肺癌における 2 次治療 としての有効性が示され, 次いで 1 次治療, あるいは化 学療法との併用療法の有効性が確認された。近年では作 用機序の異なる ICIs の 2 剂併用療法 (PD-1 抗体+ CTLA-4 抗体の併用)についても使用可能となった. 加え て，切除不能の III 期局所進行肺癌に扔ける放射線化学 療法後の維持療法として PD-L1 抗体の有効性が確認さ れ，臨床応用がなされている。これらの結果は肺癌治療 に打いて，まさにパラダイム・シフトといえる大きな変 化をもたらした。これらの切除不能 NSCLCに対する有 効性の結果を踏まえ，より早期である切除可能 NSCLC に打ける手術との併用療法の有効性が期待されるように なった。早期探索的試験で有効性が報告されたことを踏 まえ，現在では ICIs を周術期治療に導入するための多く の第 III 相臨床研究が進行中である。周術期における ICIs 療法は期待される一方で, 有害事象による手術の遅 延や中止の問題，また創傷治瘉に与える悪影響，その他 術後の合併症の増加など, 進行 NSCLC の治療とは異な る観点での評価も必要である.

\section{2. 早期臨床試験}

前述したとおり，ICIs と手術の併用療法としてこれま でいくつかの早期探索的試験が行われている. Forde ら1 は, I IIIA 期 NSCLC 21 例に対して術前に PD-1 抗体で ある Nivolumab 単剤を 2 コース投与した後に切除を 行った結果を報告している。 21 例中 20 例に抢いて根治 的切除が可能であり，切除症例 20 例中 9 例 (45\%) の症 例で major pathological response（MPR：病理学的な残 存病変の割合が $10 \%$ 未満となる効果) が得られたとして いる. 研究では, 画像的な効果と病理学的な効果の乘離 という特異な現象が報告されている．特に画像上腫瘍の 増大が確認された症例であっても，病理学的には MPR が確認された症例があったことは興味深い。これは進行 NSCLCに対するICIs 療法でしばしば経験される pseudo-progression をみている可能性があり，今後さら なる検討が望まれる。そ他にも病理学的な抗腫瘍効果 は腫瘍の PD-L1 発現や組織型には関連しなかったが, 腫 瘍の遺伝子異常数を示す tumor mutation burden
（TMB）と関連を認めるという興味深い結果も示されて いる. また，腫瘍の局所や末梢血中に腫瘍特異的な $\mathrm{T}$ 細胞が確認されたことは重要な知見である。本治療にお いて最も危惧されるのは安全性であるが, 治療に関連す ると考えられる有害事象の発生は $23 \%$ にとどまり， Grade 3 以上の有害事象は 1 例のみであったとされ，そ の安全性についても言及されている。研究については術 式や周術期合併症に関する続報も報告されている. 2 手 術術式は肺葉切除から全摘まで様々であるが, 20 例中 13 例については胸腔鏡手術あるいはロボット支援手術が行 われた。また，術後合併症は $50 \%$ に認められた。肺塞栓 や心筋梗塞といった重篤なものも認められたが，手術関 連死亡はなかったとしている。 この他にも, 同様の試験 がいくつか行われている．代表的なものとして PD-L1 抗体である Atezolizumabを術前に 2 回投与した後に手 術を行う LCMC3 試験がある. 3 本試験では 77 症例中 15 例（19\%）でMPR が確認されたとしている．同様に Pembrolizumabによる術前治療の検討や, 4 さらには PD-1 抗体に加え，CTLA-4 抗体である Ipilimumab を併 用した術前療法 5 などが実施されいずれも有効性が示唆 される結果である。このような複数の探索的試験の結果 を踏まえ, 数多くの第 III 相試験が進行中である.これら の現状について次項で述べる.

\section{3. 現在進行中の第 III 相臨床試験}

現在複数の周術期 ICIs 治療に関する検証的な臨床研 究が進行している. 6.7 現在行われている第 III 相試験を Table 1, Table 2 にまとめた. Table 1 は術前治療に関す る試験である。これらの研究の中で先んじて行われてき たのが, CheckMate816 試験である. Table 1 に記載のと おり当初は Nivolumab と Ipilimumab の併用に関する試 験群が設定されていたが，試験途中で変更となり，実質 的には化学療法群と化学療法 + ICIs 併用群の 2 群の比 較試験として進められた。その結果の一部は既に第一報 として 2021 年の米国癌学会 $(\mathrm{AACR})$ にて報告された。 本試験の主要評価項目は pathological complete response（pCR）と無再発生存期間（event-free survival : EFS）の 2 つが設定されている. 報告では $\mathrm{pCR}$ を含めた 病理学的効果の結果と治療関連有害事象に関しての結果 が報告された。まず $\mathrm{pCR}$ の割合は Nivolumab + 化学療 法群で $24.0 \%$ に対して, 化学療法群は $2.2 \%$ であり有意に

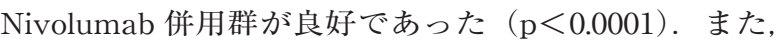

MPR についても $36.9 \%$ vs. $8.9 \%$ と有意に Nivolumab 併 用群が良好であった。一方で有害事象については治療関 連有害事象が $33.5 \%$ vs. $36.9 \%$ ，有害事象によって手術が できなかった症例は各群とも 2 例ずつであった。また手 術関連有害事象は $11.4 \%$ vs. $14.8 \%$ といずれも同等の結 
Table 1. Ongoing Phase III Neo-adjuvant Trial

\begin{tabular}{|c|c|c|c|c|c|}
\hline $\begin{array}{l}\text { Trial name/ } \\
\text { Registry ID }\end{array}$ & $\mathrm{N}$ & $\begin{array}{l}\text { Target } \\
\text { stage }\end{array}$ & Treatment & Treatment after surgery & Endpoint \\
\hline $\begin{array}{l}\text { KEYNOTE-671/ } \\
\text { NCT03425643 }\end{array}$ & 786 & IIB-IIIA & $\mathrm{Cx} \pm$ Pembrolizumab & Pembrolizumab/Placebo & EFS, OS \\
\hline $\begin{array}{l}\text { CheckMate816/ } \\
\text { NCT02998528 }\end{array}$ & 642 & IB-IIIA & $\begin{array}{c}\mathrm{Cx} \pm \text { Nivolumab/ } \\
\text { Nivolumab + Ipilimumab }\end{array}$ & Chemotherapy \pm Radiotherapy & pCR, EFS \\
\hline $\begin{array}{l}\text { Impower030/ } \\
\text { NCT03456063 }\end{array}$ & 302 & II-IIIB & $\begin{array}{c}\mathrm{Cx} \pm \\
\text { Atezolizumab }\end{array}$ & Atezolizumab/Placebo & EFS/MPR \\
\hline $\begin{array}{l}\text { AEGEAN/ } \\
\text { NCT03800134 }\end{array}$ & 300 & II-IIIB & $\begin{array}{c}\mathrm{Cx} \pm \\
\text { Durvalumab }\end{array}$ & Durvalumab & MPR \\
\hline $\begin{array}{l}\text { CheckMate77T/ } \\
\text { NCT04025879 }\end{array}$ & 452 & II-IIIB & $\mathrm{Cx} \pm$ Nivolumab & Nivolumab/Placebo & EFS \\
\hline
\end{tabular}

N: number of patients, Cx: platinum doublet chemotherapy, EFS: event-free survival, OS: overall survival, pCR: pathological complete response, MPR: major pathological response.

Table 2. Ongoing Phase III Adjuvant Trial

\begin{tabular}{lcccc}
\hline \multicolumn{1}{c}{$\begin{array}{c}\text { Trial name/ } \\
\text { Registry ID }\end{array}$} & $\mathrm{N}$ & $\begin{array}{c}\text { Target } \\
\text { stage }\end{array}$ & Treatment & Endpoint \\
\hline $\begin{array}{l}\text { ALCHEMIST, ANVIL/ } \\
\text { NCT02595944 }\end{array}$ & 900 & IB-IIIA & Nivolumab & EFS, OS \\
$\begin{array}{l}\text { Impower010/ } \\
\text { NCT02486718 }\end{array}$ & 1280 & IB-IIIA & $\mathrm{Cx} \times 4 \rightarrow$ Atezolizumab/Placebo & EFS \\
$\begin{array}{l}\text { BR.31/ } \\
\text { NCT02273375 }\end{array}$ & 1360 & IB-IIIA & Durvalumab & EFS \\
$\begin{array}{l}\text { KEYNOTE-091/ } \\
\text { NCT02504372 }\end{array}$ & 1080 & IB-IIIA & Pembrolizumab & EFS \\
$\begin{array}{l}\text { ALCHEMIST Chemo-IO/ } \\
\text { NCT04267848 }\end{array}$ & 1263 & IB-IIIA & $\mathrm{Cx} \times 4 / \mathrm{Cx} \times 4+$ Pembrolizumab/Cx $\times 4 \rightarrow$ & DFS, OS \\
\end{tabular}

N: number of patients, Cx: platinum doublet chemotherapy, EFS: event-free survival, OS: overall survival, DFS: disease-free survival.

果であったと報告されており，優れた抗腫瘍効果と一定 の安全性が確認されたと考えて良い.今後 EFS の延長な どの，遠隔期の結果が待たれる.

その他の試験のデザインはいずれも化学療法と化学療 法 + ICIs 併用群との比較試験である. Endpoint は様々で あるが, 主に EFS もしくは MPR が設定されている. 術 前治療の試験であるため, 本質的には全生存期間（overall survival：OS）もしくは EFS が設定されるべきであ るが，後述するように MPR が OS の surrogate marker となる可能性があるとの認識に基づき MPR の設定がな されている試験がある。なお，これらの術前治療の 5 試 験のうち先述したCheckMate816 試験を除いた 4 試験 は維持療法として術後にも ICIs を投与することとされ ており, 術前, 術後補助療法を一連の治療として行うこ とで検討が進められている.

Table 2 は術後補助療法としての ICIs 療法についてま とめたものである. 術後補助療法においても同様に, 現 在実臨床においては使われているICIs の 4 用を用いた 試験が行われている。術後補助療法の試験においては
EFS を endpoint とせざるを得ないため，試験期間が長 期化し，1000 例規模といった多くの症例数が必要となる ことは避けられない。このうち Impower010 試験につい ては 2021 年の米国臨床腫瘍学会 (ASCO) にて結果が報 告された. 9 本試験は IB〜IIIA 期の NSCLCで，手術後 に最大 4 サイクルの Cisplatinを含む補助化学療法を受 けた患者を対象に，支持療法（BSC）と比較して PD-L1 抗体の Atezolizumab の有効性と安全性を評価したもの である。最終的に 1005 例の症例が登録され, Atezolizu$\mathrm{mab}$ 群, $\mathrm{BSC}$ のみ群に $1: 1$ の割合で症例登録が行わ れた。主要評価項目の中の 1 つの対象である II〜IIIA 期, PD-L1 > $1 \%$ の症例において Atezolizumabの 1 年間 の投与は再発リスクを $34 \%$ 低下させることが確認され た（hazard 比：0.66, $\mathrm{p}=0.004)$. また，同時にPD-L1 陰性を含めたすべての II〜IIIA 期の症例において再発 リスクを $21 \%$ 低下させることが示されたが, 陰性例に限 定した場合の効果については今後の確認が必要かもしれ ない. なお，本試験では IB 期症例についても登録が行わ れているが，特に IB 期症例における有効性については 
十分な議論が必要であり, 今後の解析結果が待たれると ころである。

術後補助療法における重要な視点としては, バイオ マーカーによる治療対象の選別が挙げられる。術後補助 療法においては, 十分な手術検体を用いたバイオマー カーの解析が可能となるため, 今後の新たな展開が期待 される. PD-L1の発現のみならず, 今後 ICIs がより有効 である症例群を抽出することは臨床的にも医療経済的に も重要と考えられる. 当該領域の研究はまだ途上にある が，バイオマーカー候補の 1 例として腫瘍の TMB が考 えられる. TMBについてこれまでICIs のバイオマー カーとしての有用性に関していくつかの解析が行われて いるが, 再現性をもって TMB が ICIs の効果予測因子で あるとの報告はない. 我々の解析によれば, TMB が高值 である症例では術後再発を来しやすく, また術後の補助 化学療法の効果がそしいことを報告している.10 ICIs の治療効果そのものを示した結果ではなく，またあくま でも後ろ向きの解析ではあるが，少なくとも TMB が高 值の症例では従来の術後化学療法のみでは再発抑制には 十分でないことが示唆される結果であり, これらの患者 群に対してICIs を併用する理論的根拠になるかもしれ ない. 一方で効果を予測するのみでなく, そもそも ICIs の効果が限定されるような, 耐性メカニズムを有する症 例を選別する試みもある。その 1 例として, 我々が検討 している $\beta$-catenin 高発現腫瘍が挙げられる。 $\beta$-catenin 発現腫瘍は各種免疫細胞の局所への浸潤が低下してお り, ICIs の効果が低いことが知られており臨床的にも重 要である. 11 その他にも切除検体を用いたバイオマー カーの解析に関する検討は数多く進められており, 今後 これらの結果が期待される.12,13

\section{ICls 治療に特徵的な病理学的評価}

先述したように周術期治療, 特に術前治療として ICIs 療法を行った場合の利点として, 病理学的な解析が詳細 に行える点が挙げられる．既にいくつかの評価に関する 検討が行われている.1つは，既に述べている MPR があ る.腫瘍の残存が $10 \%$ 未満である場合を MPR としてい るが, MPR が得られた症例と残存病変の割合が $71 〜 ~$ 100\%の症例を比較すると 4 5 倍リスクが高くなると 報告されており， OSの surrogate marker として重要で あることが示されている.14 先述したとおり，いくつか の第 III 相試験では MPR を endpoint としているものも みられる。

また，病理学的な評価として単に残存病変の有無のみ ならず,副次的な所見も重要であることも示されている. 3 次リンパ節構造 (tertiary lymphoid structure : TLS)の 構築や cholesterol clefts といった所見が ICIs 治療後の
効果に特徽的であり, その効果を判定する際に重要な所 見であることが指摘されている.15 またこれらの所見を immune-related pathological response criteria (iPRC) と して総合的に評価する方法も提唱されており, 今後のさ らなる解析が注目される. 16

\section{5. おわりに}

進行再発 NSCLCに対する ICIs 療法の有効性を踏ま え, 周術期の ICIs 併用療法の有効性を検証する国際共同 第 III 相試験が進行中である. 術前, 術後補助療法のいず れにおいても既に有効性が報告されつつあり, 臨床応用 が期待されている，一方で，周術期に使用する場合に最 も注意すべき課題である手術に与える影響を十分考慮す る必要がある．特に手術の遅延や術後合併症など, 手術 の安全性に対する影響についてはしっかりとした評価が 必要である。また, 周術期への ICIs 療法の導入によって 手術成績の向上はもちろん, 前後に手術検体を解析でき る利点を活かした新たなバイオマーカーの解析や耐性メ カニズムの解明にも期待したい.

本論文内容に関連する著者の利益相反 : 鈴木弘行 [日当・講 演料] 中外製薬 (株), 小野薬品工業 (株), アストラゼネカ (株)，日本イーライリリー(株), MSD (株) [研究費・助成金 などの総額］日本ベーリンガーインゲルハイム（株），MSD (株), ブリストル・マイヤーズスクイブ(株), 小野薬品工業 (株), 大鵬薬品工業 (株) [奨学 (奨励) 寄附金などの総額］小 野薬品工業 (株), 日本イーライリリー（株）

\section{REFERENCES}

1. Forde PM, Chaft JE, Smith KN, Anagnostou V, Cottrell TR, Hellmann MD, et al. Neoadjuvant PD-1 Blockade in Resectable Lung Cancer. N Engl J Med. 2018;378:19761986.

2. Bott MJ, Yang SC, Park BJ, Adusumilli PS, Rusch VW, Isbell JM, et al. Initial results of pulmonary resection after neoadjuvant nivolumab in patients with resectable non-small cell lung cancer. J Thorac Cardiovasc Surg. 2019; 158:269-276.

3. Kwiatkowski DJ, Rusch VW, Chaft JE, Johnson BE, Nicholas A, Wistuba II, et al. Neoadjuvant atezolizumab in resectable non-small cell lung cancer (NSCLC): Interim analysis and biomarker data from a multicenter study (LCMC3). J Clin Oncol. 2019;37(Suppl):8503.

4. Eichhorn F, Klotz LV, Bischoff H, Thomas M, Lasitschka F, Winter H, et al. Neoadjuvant anti-programmed Death1 immunotherapy by Pembrolizumab in resectable nodal positive stage II/IIIa non-small-cell lung cancer (NSCLC): the NEOMUN trial. BMC Cancer. 2019;19:413.

5. Cascone T, William WN, Weissferdt A, Lin HY, Leung $\mathrm{CH}$, Carter BW, et al. Neoadjuvant nivolumab (N) or nivolumab plus ipilimumab (NI) for resectable non-small 
cell lung cancer (NSCLC): Clinical and correlative results from the NEOSTAR study. J Clin Oncol. 2019;37(Suppl): 8504 .

6. Kang J, Zhang C, Zhong WZ. Neoadjuvant immunotherapy for non-small cell lung cancer: State of the art. Cancer Commun. 2021;41:287-302.

7. Ni J, Huang M, Zhang L, Wu N, Bai CX, Chen LA, et al. Clinical recommendations for perioperative immunotherapy-induced adverse events in patients with non-small cell lung cancer. Thorac Cancer. 2021;12:14691488.

8. Forde PM, Spicer J, Lu S, Provencio M, Mitsudomi T, Awad MM, et al. Nivolumab (NIVO) + platinum-doublet chemotherapy (chemo) vs chemo as neoadjuvant treatment (tx) for resectable (IB-IIIA) non-small cell lung cancer (NSCLC) in the phase 3 CheckMate 816 trial. Cancer Res. 2021;81(Suppl):Abstract CT003.

9. Wakelee HA, Altorki NK, Zhou C, Csőszi T, Vynnychenko IO, Goloborodko O, et al. IMpower010: Primary results of a phase III global study of atezolizumab versus best supportive care after adjuvant chemotherapy in resected stage IB-IIIA non-small cell lung cancer (NSCLC). J Clin Oncol. 2021;39(Suppl):Abst. 8500.

10. Owada-Ozaki Y, Muto S, Takagi H, Inoue T, Watanabe Y, Fukuhara M, et al. Prognostic Impact of Tumor Mutation Burden in Patients With Completely Resected NonSmall Cell Lung Cancer: Brief Report. J Thorac Oncol. 2018;13:1217-1221.
11. Muto S, Ozaki Y, Yamaguchi H, Mine H, Takagi $\mathrm{H}$, Watanabe M, et al. Tumor $\beta$-catenin expression is associated with immune evasion in non-small cell lung cancer with high tumor mutation burden. Oncol Lett. 2021;21:203.

12. Hofman P, Heeke S, Alix-Panabières C, Pantel K. Liquid biopsy in the era of immuno-oncology: is it ready for prime-time use for cancer patients? Ann Oncol. 2019;30: 1448-1459.

13. Indini A, Rijavec E, Grossi F. Circulating Biomarkers of Response and Toxicity of Immunotherapy in Advanced Non-Small Cell Lung Cancer (NSCLC): A Comprehensive Review. Cancers. 2021;13:1794.

14. Hellmann MD, Chaft JE, William WN Jr, Rusch V, Pisters KMW, Kalhor N, et al. Pathological response after neoadjuvant chemotherapy in resectable non-smallcell lung cancers: proposal for the use of major pathological response as a surrogate endpoint. Lancet Oncol. 2014; 15:e42-e50.

15. Stein JE, Lipson EJ, Cottrell TR, Forde PM, Anders RA, Cimino-Mathews A, et al. Pan-Tumor Pathologic Scoring of Response to PD-(L)1 Blockade. Clin Cancer Res. 2020;26: 545-551.

16. Cottrell TR, Thompson ED, Forde PM, Stein JE, Duffield AS, Anagnostou V, et al. Pathologic features of response to neoadjuvant anti-PD-1 in resected non-small-cell lung carcinoma: a proposal for quantitative immune-related pathologic response criteria (irPRC). Ann Oncol. 2018;29: 1853-1860. 